\title{
KOMUNIKASI PEMBANGUNAN DALAM PENDAMPINGAN KOMUNITAS PETERNAK SAPI PERAH
}

\author{
Development Communication in Community Farmer's Dairy Cow \\ L.V. Ratna Devi Sakuntalawati \\ Program Studi Sosiologi, FISIP, Universitas Sebelas Maret \\ E-mail: ratnadevi.solo@gmail.com
}

\begin{abstract}
The assistance of the dairy farmers community in implementing the use of herbal probiotics as an innovation program requires communication. This program is a behavior change program in dairy farming by farmers. The communication needed is intensive between companion and community. This is an interaction between the two because of cooperation. Collaboration because of the same interest, so it must be communicated. It also requires communication that can lead to collective action, because there is participation in the process of change / development. Communication is a feature of development communication. Therefore, the aim of the study is to explain development communication in the assistance of the community of dairy farmers. The method used is qualitative research methods. The study was conducted in the village of Nogosaren, Getasan sub-district, Semarang Regency. The sampling technique uses purposive sampling. The population is 932 breeders, which are used to attract informants as research samples. The technique of collecting data using in-depth interviews. The results of the study indicate that the interaction between companion and community requires a centralized model of communication to collaborate. There are three main elements in centralized communication, which are contained in mentoring activities. Mentoring activities about program socialization are elements of physical reality. Mentoring activities on identifying community problems, awareness of farmers to improve livestock cultivation, application of herbal probiotic innovations including supporting elements of use and how to procure supporting elements, are elements of psychological reality. Mentoring activities on community agreements in the implementation of procurement of support for the use and use of herbal probiotics are an element of social reality. In social reality, there is a community's interest in engaging in activities that are not separated from their basic needs, namely, increasing milk yields to increase income. Discussion of research results; development communication, which is communication for change, is needed in every assistance. All realities which are the main elements are used to convey information needed by the community, educational efforts for the community, increasing knowledge and increasing skills to be able to implement the program. The four stages carried out by the companion contained communication. The conclusion of the study is development communication or communication for change using a centralized communication model. This model colors the entire farmer community assistance activities, because in the mentoring steps there are elements of a centralized communication model, namely physical, psychological and social reality.
\end{abstract}

Keywords: communication, community, development, mentoring, breeders

\begin{abstract}
ABSTRAK
Pendampingan komunitas peternak sapi perah dalam pelaksanaan penggunaan probiotik herbal sebagai program inovasi, membutuhkan komunikasi. Program ini merupakan program perubahan perilaku dalam budidaya sapi perah oleh peternak. Komunikasi yang dibutuhkan adalah yang intensif antara pendamping dan komunitas. Ini merupakan interaksi diantara keduanya karena adanya kerjasama. Kerjasama karena adanya kepentingan yang sama, sehingga harus dikomunikasikan. Dibutuhkan juga komunikasi
\end{abstract}


yang dapat menimbulkan tindakan kolektif, karena ada partisipasi dalam proses perubahan/pembangunan. Komunikasi tersebut merupakan ciri komunikasi pembangunan. Oleh sebab itu, tujuan penelitian adalah menjelaskan komunikasi pembanguan dalam pendampingan komunitas peternak sapi perah. Metode yang digunakan metode penelitian kwalitatif. Penelitian dilakukan di desa Nogosaren, kecamatan Getasan, Kabupaten Semarang. Teknik sampling menggunakan purposive sampling. Jumlah populasi 932 peternak, yangdigunakan untuk menarik informan sebagai sampel penelitian. Teknik pengumpulan data menggunakan wawancara mendalam. Hasil penelitian menunjukkan bahwa interaksi antara pendamping dan komunitas membutuhkan model komunikasi memusat untuk melakukan kerjasama. Terdapat tiga unsur pokok dalam komunikasi memusat, yang terkandung dalam kegiatan pendampingan. Kegiatan pendampingan tentang sosialisasi program merupakan unsur realitas fisik. Kegiatan pendampingan tentang identifikasi masalah komunitas, penyadaran peternak melakukan pembenahan budidaya ternak, penerapan inovasi probiotik herbal termasuk elemen pendukung penggunaan serta cara pengadaan elemen pendukungnya, merupakan unsur realitas psikologis. Kegiatan pendampingan tentang kesepakatan komunitas dalam pelaksanaan pengadaan pendukung penggunaan serta penggunaan probiotik herbal merupakan unsur realitas sosial. Dalam realitas sosial, ada kepentingan komunitas untuk melibatkan diri dalam kegiatan yang tak lepas dari kebutuhan dasar mereka yaitu, peningkatan hasil susu guna peningkatan pendapatan. Bahasan hasil penelitian; komunikasi pembangunan yang merupakan komunikasi untuk perubahan, diperlukan dalam setiap pendampingan. Semua realitas yang merupakan unsur pokok digunakan untuk menyampaikan informasi yang diperlukan masyarakat, upaya pendidikan bagi masyarakat, peningkatan pengetahuan dan peningkatan ketrampilan untuk dapat melaksanakan program. Keempat tahap yang dilakukan pendamping tersebut terkandung komunikasi. Kesimpulan penelitian adalah komunikasi pembangunan atau komunikasi untuk perubahan menggunakan model komunikasi memusat. Model ini mewarnai seluruh kegiatan pendampingan komunitas peternak, karena dalam langkahlangkah pendampingan terdapat unsur-unsur model komunikasi memusat, yaitu realitas fisik, psikologi dan sosial.

Kata kunci: komunikasi, komunitas, pembangunan, pendampingan, peternak

\section{PENDAHULUAN}

Pendampingan memerlukan kegiatan penyadaran, pemahaman bersama, menarik minat peternak untuk berpartisipasi dalam program, sampai pada pelaksanaan penggunaan probiotik herbal, membutuhkan komunikasi. Komunikasi yang dapat menimbulkan tindakan kolektif, tentunya komunikasi yang memiliki model yang dapat diacu sebagai model yang mampu mewarnai seluruh kegiatan pendampingan.

Dalam observasi didapat permasalahan peternak sapi perah yang ada di desa Nogosaren, teridentifikasi sebagai berikut:

- Pengetahuan dan pemahaman peternak tentang budidaya sapi perah masih konvensional. Rata-rata perekor sapi hanya 7-8 liter per hari, dengan index fat dibawah standar.

- Produktivitas sapi rendah yang ditandai produksi susu rendah, kualitas susu rendah dan permasalaha reproduksi. Ditandai dengan pemberian pakan yang masih dibawah standar dan tidak sesuai dengan kebutuhan sapi perah.

- Sikap mental peternak hingga saat ini masih belum mau memperhatikan ternaknya, artinya belum mau berperilaku merawat ternaknya dengan baik. Nampak bahwa kwalitas susu rendah sehingga harga yang diterima rendah. 
Berdasar permasalah peternak, dilakukan pendampingan yang menghasilkan sebagai berikut:

- Terdapat perubahan sikap dan perilaku peternak dalam memelihara sapi perah. Hal ini nampak dari adanya perubahan kandang, kebersihan saat pemerahan, rasa memiliki pada ternak dan kepedulian pada lingkungan.

- Produksi susu setelah program mengalami kenaikan rata-rata 2 liter per ekor per hari atau awal 8 liter per ekor per hari menjadi 10 nliter per ekor per hari.

- Terdapat kenaikan kualitas susu dari semula, yaitu kenaikan standar fat sesuai dengan standar Industri Pengelola Susu.

Keberhasilan pendampingan ini tidak lepas dari komunikasi yang digunakan oleh pendamping. Komunikasi yang dimaksud adalah komunikasi perubahan atau komunikasi pembangunan. Oleh sebab itu penelitian ini tertarik menggambarkan komunikasi pembangunan dalam pendampingan komunitas peternak sapi perah.

Permasalahan yang hendak dijawab adalah: Bagaimana komunikasi pembangunan dalam pendampingan komunitas peternak sapi perah? Serta menjawab tujuan penelitian yaitu menggambarkan komunikasi pembangunan dalam pendampingan komunitas peternak sapi perah.

\section{TINJAUAN PUSTAKA}

Dalam penelitian ini digunakan konsep komunikasi pembangunan yaitu proses ingteraksi yang terjadi antar pemangku kepentingan pembangunan adalah karena adanya kerjasama untguk mencapai goal. Kerjasama timbul karena adanya kepentingan yang sama sehingga harus dikomunikasikan agar memiliki tafsiran yang sama terhadap perilaku antar pemangku kepentingan. Selain itu perlu ada partisipasi didalamnya (Rogers, 1962; Susanto, 1977; Effendi, 1984; Mardikanto, 2010). Konsep pendampingan adalah proses pemadirian masyarakat (Priyono dan Pranaka, 1996).

\section{METODE PENELITIAN}

Jenis penelitian yang digunakan adalah penelitian deskriptif kualitatif. Lokasi yang dipilih adalah desa Nogosaren, kecamatan Getasan, kabupaten Semarang. alasan pemilihan lokasi, karena tidak banyaknya bantuan yang datang baik dari pemerintah maupun non pemerintah. Unit analisis penelitian adalah peternak yang telah mendapatkan pendampingan. Sumber data primer diperoleh secara langsung dari para informan. Informan penelitian ini adalah peternak sapi perah. Sumber data sekunder diperoleh dari kantor desa Nogosaren. Teknik pengumpulan data digunakan wawancara mendalam dengan menggunakan instrumen interview guide. Teknik pengambilan sampel menggunakan purposive. Untuk menguji validitas data, peneliti melakukan triangulasi data khususnya pemeriksaan yang memanfaatkan penggunaan sumber. Analisis data dipergunakan cara analisis tiga alur, yaityu reduksi data, penyajian data dan penarikan kesimpulan.

\section{HASIL DAN PEMBAHASAN}

Hasil penelitian menunjukkan bahwa dalam pendampingan kegiatan, dilakukan langkah-langkah sebagai berikut: 1) Pemetaan komunitas untuk mengetahui kondisi dan situasi budaya ternak sapi perah. 2) Sosialisasi program (penerapan inovasi probiotik herbal.3) Identifikasi masalah komunitas tentang 
budidaya ternak sapi perah. 4) FGD tentang hasil pemetaan, yang dikaitkan dengan hasil identifikasi masalah, untuk mendapatkan pemahaman bersama tentang kondisi ternak. Hal ini merupakan acuan untuk penyadaran peternak dalam melakukan langkah-langkah pembenahan budidaya ternaknya. 5) FGD tentang program yang diinformasikan, yaitu penerapan probiotik herbal. Disini dibicarakan tentang elemen-elemen pendukung penggunaan probiotik herbal, efeknya baik positif maupun negatif dan hasil yang ingin dicapai bersama. 6) FGD cara pengadaan elemen-elemen pendukung penggunaan probiotik herbal, tentang pengadaan tempat minum dan tempat makan sapi, dibuat sesuai keinginan dan kemampuan komunitas. 7) pelaksanaan pembuatan tempat minum dan dan tempat makan sesuai kesepakatan komunitas. 8) Penggunaan probiotik herbal. 9) Evaluasi terhadap penggunaan probiotik herbal.

Langkah-langkah pendampingan jika dikaji dengan unsur pokok dalam komunikasi memusat, maka: pada langkah pendampingan yang 2) adalah merupakan unsur realitas fisik. Langkah pendampingan 3), 4), 5), 6), merupakan unsur realitas psikologis. Langkah pendampingan 7) dan 8), merupakan unsur realitas sosial. Ketiga unsur ini merupakan unsur pokok komunikasi memusat.

Dalam unsur realitas fisik, komunikasi dilakukan melalui FGD-FGD untuk memberikan informasi tentang penerapan penggunaan probiotik herbal, untuk mendapatkan respon. Komunikasi yang terbangun memunculkan makna bahwa ada kesepahaman bersama antara pendamping dan komunitas. Selanjutnya muncul tindakan kolektif untuk mengerti dan percaya terhadap informasi yang disampaikan pendamping. Ini merupakan realitas psikologis. Adanya tindakan kolektif memunculkan kesepakatan bersama untuk melaksanakan pembuatan tempat minum dan makan sebagai elemen penunjang penggunaan probiotik herbal, sampai pada penggunaan probiotik herbal. Ini merupakan realitas sosial. Dalam realitas sosial ada kepentingan komunitas untuk melibatkan diri dalam kegiatan yang tak lepas dari kebutuhan dasar mereka, sesuai dengan pandangan Maslow bahwa kebutuhan dasarnya adalah meningkatkan hasil susu guna peningkatan pendapatan (Siahaan, 1998).

Setiap pendampingan diperlukan komunikasi (Mardikanto, 2010) untuk 1) menyampaikan informasi yang diperlukan masyarakat, berupa informasi tentang penggunaan probiotik herbal. Informasi ini diberikan atas dasar proses penyadaran pada peternak tentang kemerosotan hasil susu baik kualitas maupun kuantitas. 2) adanya upaya pendidikan bagi masyarakat untuk membantu belajar mengubah cara pandang pada ternak agar menghasilkan jumlah peningkatan susu. 3) peningkatan pengetahuan dengan cara memberikan pelatihan tentang bididaya ternak dengan menggunakan probiotik herbal. 4) peningkatan ketrampilan untuk dapat melaksanakan penggunaan probiotik herbal.

Hasil penyadaran adalah melalui belajar mampu mengubah cara pandang terhadap ternak, karena menyadari bahwa alam mereka mendukung pemeliharaan sapi perah. Ada pergeseran cara menghargai ternak sebagai "rojo koyo" dengan memelihara serta merawat sehingga menghasilkan peningkatan jumlah susu. Peternak menyadari bahwa peningkatan susu disebabkan oleh kesejahteraan hewan. Pelatihan yang diperoleh menjadikan peternak memiliki aspirasi baru tentang budidaya ternak maupun penggunaan probiotik herbal. Sekaligus menerapkan tekhin baru dalam memelihara ternak, yaitu penggunaan probiotik herbal, karan memberi mabfaat peningkatan kualitas dan kuantitas susu. Ini semua merupakan peranan komunikasi dalam proses pendampingan. 
Pembahasan terhadap hasil penelitian yang diperoleh, bahwa komunikasi pembangunan yang digunakan dalam pendampingan menggunakan komunikasi memusat seperti pendapat Schramm (Mardikanto, 2010), yaitu proses penggunaan pesan oleh dua orang atau lebih, dimana semua pihak saling berganti peran sebagai pengirim dan penerima pesan, sampai ada saling pemahaman atas pesan yang disampaikan oleh semua pihak. Hasil penelitian juga menerapkan 3 unsur komunikasi memusat tentang unsur realitas, psikologis dan sosial.Model yang paling tepat untuk dikembangkan dalam proses komunikasi pembangunan. Sebab dalam kegiatan komunikasi pembangunan, proses komunikasi antara pendamping dan peternak tidak hanya terhenti jika pendamping telah menyampaikan penggunaan probiotik herbal, tetapi seringkali (dan seharusnya memang begitu) komunikasi baru terhenti jika peternak telah menerima dan atau melaksanakan penggunaan probiotik herbal. Dalam melakukan komunikasi juga tergambar peranan komunikasi seperti digambarkan oleh Mills (Mardikanto, 2010).

\section{KESIMPULAN DAN SARAN}

Komunikasi pembangunan/perubahan yang digunakan dalam pendampingan peternak sapi perah, dilakukan secara personal maupun impersonal, maka saluran komunikasi yang paling tepat adalah saluran inter personal/ diantara orang perorang, melalui FGD maupun perorangan. Komunikasi ini sangat bermanfaat untuk mempengaruhi peternak agar menggunakan probiotik herbal. Ada proses dialogical encounter antar pendamping dengan peternak yang memerlukan sense of trustdiantara keduanya. Komunikasi intensif harus dilakukan untuk saling belajar, sehingga terbentuk pemahaman bersama terhadapa penggunaan probiotik herbal. Model komunikasi yang tepat untuk hal tersebut adalah komunikasi memusat. Semua unsur dalam komunikasi ini mewarnai langkah pendampingan.

\section{DAFTAR PUSTAKA}

Mardikanto, T., 2010. Sistem Penyuluhan Pertanian. Surakarta: Penerbit UNS Press.

Mardikanto, T., 2010. Komunikasi Pembangunan. Surakarta: UNS Press.

Mulyana. W.S. 2009. Teori Difusi Inovasi. Wordpress.com.

Priyono dan Pranaka. 1996. Pemberdayaan, Konsep, Kebijakan dan Implementasi. Jakarta: CSIS.

Siahaan, 1998. Komunikasi Pemahaman dan Penerapannya. Jakarta: PT BPK Gunung Mulia. 